\title{
Gender Equality Principle: Application in ECtHR's Practice
}

\section{Svitlana KARVATSKA ${ }^{1}$, Ivan TORONCHUK ${ }^{2}$, Alyona MANYK ${ }^{3}$}

${ }^{1}$ LL. D (Doctor of Law), Associate Professor, Department of European Law and Comparative Law Studies, Yuriy Fedkovych Chernivtsi National University,

Ukraine.s.karvatska@,chnu.edu.ua

2 Ph. D, Associate professor, Department of European Law and Comparative Law Studies, Yuriy Fedkovych Chernivtsi National University, Ukraine.

i.toronchuk@,chnu.edu.ua

${ }^{3} \mathrm{Ph}$. D, Senior Lecturer, Department of European Law and Comparative Law Studies, Yuriy Fedkovych Chernivtsi National University, Ukraine. a.manyk@,chnu.edu.ua

\begin{abstract}
The article is devoted to analyzing the decisions of the European Court of Human Rights (ECtHR), which concerned the issue of gender equality, distinctive features of the application of a gender equality principle by the ECtHR. Based on a study of ECtHR's rulings, it is noted that the concept of gender equality as one of the objectives of the Council of Europe has been applied by the ECtHR since the early 1990s. The ECtHR's approaches to dealing with gender equality cases are characterized both through the prism of non-discrimination (applying Article 14 of the European Convention on Human Rights in combination with other articles) and through complaints about violations of rights guaranteed by other ECHR articles. The analysis shows that, on the one hand, ECtHR emphasizes that gender equality is considered as one of the critical principles of the ECHR. However, on the other hand, significant difficulty in gender discrimination cases is the Court's possibility to refuse to analyze the case in the context of Article 14th content of the Convention. The possibility of giving the Court to states a vast margin of appreciation in determining domestic policies on gender equality is ambiguously manifested in judicial practice. The conclusion states that the need to ensure gender equality can be considered by the ECtHR as a legitimate aim and can serve as an appropriate basis for interfering with the exercise of certain rights and freedoms enshrined in the Convention.
\end{abstract}

Keywords: gender equality, ECtHR case law, discrimination, domestic violence, gender stereotypes

How to cite: Karvatska, S., Toronchuk, I., \& Manyk, A. (2021). Gender Equality Principle: Application in ECtHR's Practice. Logos Universality Mentality Education Novelty: Law, 9(1), 83-95. https://doi.org/10.18662/lumenlaw/9.1/59 


\section{Introduction}

Achieving gender equality is a critical element in implementing the Council of Europe's mission, which is to protect human rights, support democracy and uphold the rule of law (Council of Europe, 2018). Gender equality implies equal rights for women and men, girls and boys, as well as their even importance, opportunities, responsibilities, and participation in all spheres of public and private life. But, as the new Council of Europe`s Gender Equality Strategy (2018) points out, despite the progress was made and the legal status of women in Europe has improved over the last decades, practice is still far away from theory. Gender inequality exists in many areas, assigning women and men their traditional roles and restricting women from exercising their fundamental rights. Gender stereotypes are biased social and cultural patterns or ideas giving men and women the characteristics and functions defined and limited by their gender, which are a severe obstacle to achieving full gender equality (Council of Europe, 2018).

The problems faced by Council of Europe member-states in the process of implementing the Strategy for 2014-2017 were related to events of global and regional significance, such as adverse reaction to women's rights, unequal power structures and the continuation of gender-based violence, threats to women human rights defenders, limited participation of women in political life and decision-making, gender bias and stereotypes, sexism and discrimination against women, including sexist statements online, offline, and even during political discourse, limited access to highquality employment and financial resources, lack of social and economic infrastructure for the realization of equal rights for men and women (such as the availability of kindergartens, sufficiently paid childcare leave, parental benefits, etc.) (Council of Europe, 2018).

Regular monitoring and research show that progress on women's political participation, access to justice, and the eradication of harmful gender stereotypes and sexism is very slow. One of the clearest examples of inequality between women and men is violence against women. It is interpreted as a violation of women's rights and a significant obstacle to gender equality. Factors such as the increased popularity of nationalism and populism and their proponents' attacks on women's rights, the influx of migrants and refugees, resources reduction for gender equality mechanisms and policies, non-compliance with agreed standards have created new challenges and exacerbated some of the problems continuing to impede the achievement of full respect for equal rights for women and men (Council of Europe, 2018). 
Today in ECtHR`s practice, there are different, sometimes ambiguous approaches shaping ECtHR`s legal practice in the context of gender equality.

The article aims to summarize the peculiarities of the application of the gender equality principle by the European Court of Human Rights on the basis of the analysis of ECtHR`s decisions concerning gender equality, as well as to identify problems of ECtHR's legal practice complicating the application of substantive or transformative equality.

\section{Argument to support the thesis}

The ECtHR, for the first time, in the early 1990s, in its decision in the "Schuler-Zgraggen v. Switzerland" case, emphasized gender equality as one of the objectives of the Council of Europe and used the term" equality of the sexes" (ECtHR, 1993, para 67). Since the 2000s, decisions of ECtHR's Grand Chamber have used the terms "gender equality" (for example, in the case of "Leyla Şahin v. Turkey", ECtHR, 2009 ). By the way, in the Ukrainian legislation, the Law of Ukraine "On Ensuring Equal Rights and Opportunities for Women and Men" of September 8, 2005, uses the term "gender equality," as well as related concepts: "gender-based discrimination," "gender-based violence".

On the one hand, ECtHR's practice in gender equality cases confirms the attention of the Court to the problems of discrimination and protection of women's rights (Karvatska et. al., 2020); on the other hand, there are several critical risks for complainants in gender discrimination cases. Firstly, these risks are associated with the restrictive approach of the Court to cases consideration from the point of view of Convention's Article 14 (European Convention on Human Rights, 1950) and its tendency to pay attention to analysis subject before establishing violations of Convention's substantive rules. Secondly, when considering gender discrimination cases, the Court relies on states` margin of appreciation doctrine. States may justify intrinsically discriminatory measures based on societal perceptions of gender roles. Consequently, in some cases, this approach simplifies the legal problem by ignoring the gender aspect.

An analysis of ECtHR's case law allows us to draw several conclusions about its legal positions regarding gender discrimination. A detailed analysis reveals both fundamentally positive aspects of practice, as well as a number of points indicating Court's evasion from resolving important issues and lowering the standards for protecting individuals from discrimination. 
In discussions about the Convention's provision introducing the prohibition of discrimination, the issue of gender discrimination was not raised. In the final text of the Convention's Article 14, the enjoyment of the rights and freedoms recognized in the Convention must be ensured without any gender-based discrimination. Thus, the Convention set a specific framework for the development of ECtHR's practice, which has repeatedly interpreted the provision in question over the period of its existence. The Court noted that gender equality is considered by it as one of the fundamental principles underlying the Convention (ECtHR, 2009).

Cases concerning gender equality were most often considered by the ECtHR through the prism of non-discrimination, in other words, by applying Article 14 of the Convention (European Convention on Human Rights, 1950) in conjunction with the relevant "substantive" article of the Convention. However, practice shows that dealing with cases in the context of non-discrimination is not the only way for the ECtHR to deal with gender-sensitive cases. In some cases, the applicants did not lodge a direct complaint of discrimination and alleged a violation of the rights guaranteed by other articles of the Convention. The complaints most often concerned Article 8 of the Convention (European Convention on Human Rights, 1950), and the ECtHR, therefore, limited its consideration to this aspect only. Thus, in the case of "Konovalova v. Russia," violation of Art. 8 of the Convention (European Convention on Human Rights) was recognized for the presence of medical students during childbirth without the applicant's consent. Although the applicant did not complain of gender discrimination in the present case, the case undoubtedly concerned gender issues (ECtHR, 2014).

In ECtHR's case law, there are also many cases where violations of Article 14 of the Convention (European Convention on Human Rights) have been considered in conjunction with Article 1 of Protocol No. 1 (right to peaceful enjoyment of possessions) in the context of various social benefits, child benefits, pensions, and retirement age. For example, in the "Schuler-Zgraggen v. Switzerland" (ECtHR, 1993) case, the applicant, who had been receiving an incapacity pension for some time due to illness, had her benefits canceled after the birth of her child because her health had improved and she was by $60-70 \%$ able to take care of her home and her child. The applicant appealed against this decision, but without success. The ECtHR concluded that, given the absence of any rational, objective justification, there had been a violation of Article 14 (European Convention on Human Rights, 1950) in conjunction with Article 6 \$1 (ECtHR, 1993). 
In the "Van Raalte v. The Netherlands" case (ECtHR, 1997), the applicant was considered gender-based and discriminated against to pay compulsory payment under the Child Protection Act and the Royal Decree, whereas unmarried, childless women aged 45 and over were exempted from paying such contributions. The Amsterdam Court of Appeal rejected the applicant's complaint to the tax authorities, noting that the legislature had only taken into account the factual situation regarding the possibility of having children by men and women over the age of 45. The ECtHR stated that, for the purposes of Article 14 of the Convention, a difference in treatment is discriminatory if it is not objectively and reasonably justified. Thus, whether or not the desire to preserve the feelings of childless women of a certain age can be regarded as a legitimate aim, such reasoning cannot justify a difference in attitude on the grounds of sex, as was the case here. The ECtHR, therefore, found a violation of Article 14 of the Convention (European Convention on Human Rights) in conjunction with Article 1 of Protocol No. 1 ((ECtHR, 1997).

In the "Willis v. the United Kingdom" case, the applicant (a widower with two minor (at the time) children, whose wife died, leaving him the right to manage her real estate) was denied benefits because the law provided for payment only to "widowed mothers. " The ECtHR acknowledged that the difference in approaches to the granting of the right to men and women to receive social assistance to widows and widowed mothers did not have any objective and reasonable justification. Therefore there was a violation of Article 14 of the Convention taken in conjunction with Article 1 of the Protocol № 1 (ECtHR, 2002).

Gender-based individual characteristics were at the core of «Zarb Adami v. Malta» case on sex segregation on a gender premise within the execution of a jury member's obligations. The rationale of the ECtHR's interpretive judgments is that women and men's execution of public duties does not infer any advantage of one sex over the other, and so giving inclination to men in this capacity is unquestionably discrimination. The Court noted the necessity to clarify the law governing "gender identification" at all levels (national, European), as there is no sole approach to its interpretation: to consider it a component of "sexual introduction" or "sex separation" (ECtHR, 2006).

In the "Khamtokhu and Aksenchik v. Russia" case of 24 January 2017, the applicants complained that the fact of their sentence to life imprisonment had discriminated against them on the grounds of sex and age in violation of Article 14 of the Convention (European Convention on Human Rights) in conjunction with Article 5 of the Convention (European Convention on Human Rights). The 
ECtHR had to consider whether this difference in attitude pursued a legitimate aim and whether there was a reasonable relationship of proportionality between the means used and the aim to be achieved. However, it also had to take into account the limits of discretion enjoyed by the respondent State in the context. The ECtHR emphasized that domestic authorities, whose responsibilities include taking into account the interests of society as a whole within their competence, should enjoy wide discretion when asked to decide on sensitive issues such as penitentiary policy. In the light of the foregoing considerations, the ECtHR found that the requirements of Article 14 of the Convention (European Convention on Human Rights) in conjunction with Article 5 of the Convention (European Convention on Human Rights) concerning differences in treatment on the grounds of age or differences of sex had not been violated (ECtHR, 2017).

In "Belyayev and others v. Ukraine" case, applicants alleged that under section 151 of the Penal Code of Ukraine ("the Code"), men and women sentenced to life imprisonment were indeed entitled to one short-term visit every six months. The applicants argued that although the men and women sentenced to life imprisonment were in the same situation, they were treated differently because of their right to extended visits with family members. Such a difference in attitude, which existed before 2014, did not pursue any legitimate aim and was not sufficiently justified, in violation of Article 14 of the Convention (European Convention on Human Rights) in conjunction with Article 8 of the Convention (European Convention on Human Rights). The Court did not find any justification on the part of the Government to grant men sentenced to life imprisonment other rights to long-term visits than those enjoyed by women sentenced to life imprisonment. The foregoing considerations were sufficient for the Court to conclude that the difference in treatment complained by the applicants violated Article 14 of the Convention in conjunction with Article 8 of the Convention (European Convention on Human Rights) (Case of Belyayev and others v. Ukraine).

The ECtHR analyzed gender-sensitive situations in terms of both compliances with negative and state compliance with its positive obligations under the Convention. In one case, the ECtHR has sometimes acknowledged violations of the Convention in terms of both negative and positive obligations of the state. For example, in the "V.C. v. Slovakia" case, which concerned the sterilization of a Roma woman without her informed consent, the ECtHR found a violation of Art. 3 of the Convention (European Convention on Human Rights), like sterilization, constituted a significant interference with a person's reproductive health. The Court pointed out the non-fulfillment of negative obligations and also found a violation of Art. 8 of the 
Convention (European Convention on Human Rights) in view of the lack of guarantees which would pay particular attention to the applicant's reproductive health, which indicated that the respondent State had failed to fulfill its positive obligation to ensure the right to respect for private and family life (ECtHR, 2009).

For example, in several cases involving domestic violence (for instance, "Opuz v. Turkey"), the ECtHR found it incompatible with the State's positive obligations to respect the applicants' rights guaranteed by the Convention and the inability of national authorities to impose sanctions on the perpetrator and protect the victim. In the decision in the "Opuz v. Turkey" case a violation of Art. 2, 3, and 14 of the Convention (European Convention on Human Rights) was stated. In this case, the ECtHR also recognized for the first time that gender-based violence is a form of discrimination and described the state's obligations concerning domestic violence. For the first time in its decision, the ECtHR emphasized that domestic violence is not a private or family affair but an issue of public interest, which, in turn, requires effective action by the state (ECtHR, 2009).

The ECtHR has repeatedly applied the gender equality principle in cases where legal relations are covered by at least two priority areas of the Council of Europe's Gender Equality Strategy. Thus, combating and preventing violence against women and domestic violence is one of the strategic goals of the Council of Europe, the achievement of which will receive considerable attention in the coming years. On third September of 2019, in the case of "Levchuk v. Ukraine," the ECtHR issued the first decision against Ukraine on domestic violence. The applicant was a woman with a disability who lived on a disability pension and child support. The applicant's husband abused alcohol, threatened, and physically abused her. In 2016, the applicant filed a lawsuit to evict her ex-husband from the apartment, arguing that living in an apartment with him was incompatible with normal life. Nevertheless, the appellate court noted that there were no grounds for taking such an extreme measure as eviction. The ECtHR found that the courts' response to the applicant's eviction of her ex-husband did not correspond to the State's positive obligation to ensure adequate protection of the applicant from domestic violence. Also, the Court, in its reasoning in the decision of "Levchuk v. Ukraine" case, noted that the Council of Europe Convention on Preventing and Combating Violence against Women and Domestic Violence (Istanbul Convention) has been signed but not yet ratified by Ukraine. The court also cited OSCE research on violence against women, which found that $2 / 3$ of women $(65 \%)$ in Ukraine had experienced psychological violence 
from intimate partners. This number was $43 \%$ higher than the EU average for gender-based violence and higher than in any EU country (ECtHR, 2019).

An important strategic goal of the Council of Europe is to prevent and combat gender stereotypes and sexism, which is why the ECtHR has repeatedly spoken on this issue. As the case law of the ECtHR shows, stereotypes being the result and cause of deep-rooted attitudes, values, norms, and prejudices can be used as a basis for motivating the decisions of national authorities, including courts, in particular in traditional patriarchal societies. The most famous in this regard are the decisions of the Grand Chamber in "Konstantin Markin v. Russia," "Carvalho Pinto de Sousa Morais v. Portugal" and "S.A.S. v. France" cases.

In the "Carvalho Pinto de Sousa Morais v. Portugal" case, the applicant emphasized that the Supreme Administrative Court had reduced the amount of damages reimbursement allocated to her based on sex and age. The applicant, diagnosed with a gynecological disease, filed a civil suit against the hospital for medical negligence following surgery to treat her disease. The Administrative Court ruled in her favor and awarded her compensation. During the appeal, the Supreme Administrative Court upheld the trial court's decision but reduced damages reimbursement. It turned out that the applicant's age and sex were decisive factors in the final decision, which constituted a difference in attitude based on those grounds. In a concurring opinion, Judge of the European Court of Human Rights from Ukraine, Anna Yudkivska, noted that the ignorance of gender issues emanating from judges raises great concerns. However, the symbolic role of the judiciary in these matters consists in the rule that "these stereotypes should never come from the courtroom" (ECtHR, 2020).

In the context of sex discrimination cases, the Court quite often additionally restricts the application of Article 14 of the Convention (European Convention on Human Rights). According to its position, if a violation of the substantive article of the Convention has been found, it is not necessary to examine the case from the point of view of Article 14 (European Convention on Human Rights) unless the apparent inequality of treatment in the exercise of the relevant right is not a fundamental aspect of the case. This approach stems from cases involving nongender discrimination. For example, it is advisable to turn to the category of domestic violence cases, which has been repeatedly recognized within the framework of the Council of Europe and UN bodies as a manifestation of discrimination against women. ECtHR formes its legal opinion by the fact that domestic violence is a form of discrimination (Case of Opuz v. Turkey, ECtHR, 2020), and a failure by a State to 
fulfill its positive obligation to protect women from domestic violence need to be intentional to constitute a violation of Article 14 of the Convention (European Convention on Human Rights).

At the same time, the ECtHR's standard of proof for discriminatory treatment in domestic violence cases indicates that the Court prefers not to consider such cases from the point of view of Article 14 of the Convention (European Convention on Human Rights). The Court is generally reluctant to view claims of women, victims of domestic violence, regarding discrimination as a fundamental aspect of the case. The Court confines itself to verifying compliance by States with positive obligations under Article 8 or Article 3 of the Convention (European Convention on Human Rights), which significantly narrows the scope of the legal problem. Delay in responding and inaction of the authorities in connection with the victim's reports of violence can also be considered by the ECtHR exclusively within the framework of Articles 3 and 8 of the Convention (European Convention on Human Rights) without checking compliance with the requirements of Article (Case of Irina Smirnova v. Ukraine, ECtHR, 2016).

Thus, in addition to the objective textual limitations of Article 14 of the Convention (European Convention on Human Rights), in gender discrimination cases, the ECtHR tends to further narrow the scope of its application by shifting the "center of gravity" of the complaint from issues of discrimination to the substantive provisions of the Convention. This fact means that the Court is inclined to underestimate the importance of the gender dimension of the problems of specific categories of cases, particularly domestic violence cases. And if in such cases the ECtHR, taking the side of the applicants, establishes a violation of Convention's substantive articles of and contributes to the restoration of their rights, in many situations the refusal to consider cases from the point of view of Article 14 of the Convention (European Convention on Human Rights) on an equal basis with other circumstances may have a severe negative impact on the fight against gender-based discrimination based on sex and violation of women's rights.

In gender discrimination cases, the ECtHR tends to provide states with an extensive margin of appreciation, within which two groups of risks arise. Firstly, these risks include the possibility of justifying unequal treatment with various kinds of prejudices and stereotypes prevailing in society. Secondly, within the limits of their discretion, states can be exempted from the need to create conditions for ensuring real, and not formal, equality. 
An argument that it is possible for the Court to accept arguments based on stereotypes is also valid in cases concerning the status of women. Cases on the exercise of reproductive rights by women are especially indicative in this regard. In this category of cases, both of the risks mentioned above of applying the concept of a wide state's margin of appreciation in determining social policy, namely promoting gender stereotypes and the refusal to create conditions for ensuring gender equality, are manifested. To date, the practice of the ECtHR on the issue of the right to abortion proceeds from the fact that the state has a wide margin of appreciation in resolving this issue. In ECtHR practice, it is recognized that the refusal to carry out an abortion is a form of discrimination since it has an extraordinary impact on women. The ECtHR considers cases on the right of women to abortion in the context of the positive obligations of states under Articles 8 and 3 of the Convention (European Convention on Human Rights), related to the creation of procedural conditions for the exercise of this right in cases where abortion is permitted by law, and with observance of the requirements for the confidentiality of this procedure. At the same time, the Court recognizes that the state has a wide margin of appreciation in the legislative regulation of this issue, despite the trend of increasing access to abortion (R.R. v. Poland, ECtHR, 2011). Thus, the Court, without examining these cases within the framework of Article 14 of the Convention (European Convention on Human Rights), excludes the need to assess the prohibition of abortion both from the point of view of the stereotypes underlying such a measure (the predestination of women associated with motherhood) and from the point of view of the state's refusal to create institutional conditions that take into account the special needs of women. At the same time, this approach, reflecting increased attention to the need to eradicate the root causes of inequality, is not always implemented by the ECtHR, which, in our opinion, explains by two factors: the application of the margin of appreciation doctrine, which has obtained an independent significance, and the Court's desire to reduce the scope of the examination of the case before the violation of Convention's substantive articles and exclude article 14 from the subject of its analysis.

Women in particular, but also men, are often discriminated against on several grounds listed in Article 14 of the ECHR and complemented by the relevant case law of the ECtHR. All forms of discrimination and their nature must be taken into account to make gender equality policies and "typical policies" fully effective for women and men, girls and boys, given their differences.

The Committee of Ministers' recommendations and Parliamentary Assembly resolutions on gender equality cover many different issues, including combating 
gender discrimination, eradicating sexist vocabulary, protecting women from violence, achieving balanced participation of women and men in political and social decisionmaking, gender equality in education and sports, in media and in the audio-visual sector, ensuring standards and mechanisms for gender equality, protection and promotion of the rights of women and girls with disabilities. Those recommendations and resolutions provide the Member States with critical standards for legislation and policy implementation at the national level to be in line with established international standards in the field of gender equality.

The overall aim of the new Council of Europe gender strategy is to effectively implement gender equality policy and empower women and men in Council of Europe member states by supporting the implementation of existing documents and strengthening the Council of Europe's gender equality framework under the auspices of the Commission on Gender Equality (GEC) (Council of Europe, 2018).

\section{Conclusions}

The analysis shows that today the legal positions of the ECtHR concerning gender equality have several key features. On the one hand, the ECtHR emphasizes that gender equality is considered one of the Convention's fundamental principles. On the other hand, significant difficulty in gender discrimination cases is the Court's possibility to refuse to analyze the case in the context of the content of Article 14 of the Convention (European Convention on Human Rights). Also controversial in jurisprudence is the possibility of the Court to grant states an excessively wide margin of appreciation in determining domestic policy on gender equality. The analyzed cases show that giving states a wide margin of appreciation in determining what measures are necessary "in the public interest" may pose a threat to the implementation of the principle of non-discrimination, and therefore requires a cautious approach. However, since states' approaches can be based on deeply rooted ideas about gender roles in society, the ECtHR may not take the initiative to change such approaches. These two circumstances play a significant role in unlocking the potential of Article 14 of the Convention in terms of ensuring gender equality.

It should be noted that cases concerning gender equality were generally considered by the ECtHR through the prism of non-discrimination, in other words, by applying Article 14 of the Convention (European Convention on Human Rights) in conjunction with many articles of the Convention, which covered a wide range of legal relations concerning the right to life, the prohibition of torture, the right to a fair trial, the right to respect for private and family life, freedom of thought, conscience 
and religion, prohibition of forced labor, protection of property rights. The ECtHR analyzed gender-sensitive situations in terms of both compliances with negative and state compliance with its positive obligations under the Convention. The analysis of the decisions of the European Court of Human Rights revealed the established ECtHR's practice in cases where legal relations are covered by at least two priority areas of the Council of Europe's Gender Equality Strategy (2018), namely combating and preventing violence against women and domestic violence, as well as preventing and combating gender stereotypes and sexism. The need to ensure gender equality can be seen by the ECtHR as a legitimate aim, which can serve as an appropriate basis for interfering with the exercise of certain rights and freedoms enshrined in the Convention. At the same time, the ECtHR justifies such interference by observing the principle of the rule of law.

\section{References}

Council of Europe. (2018). Stratégie du conseil de l'europe pour l'égalité entre les femmes et les hommes 2018-2023. Adoptée par le Comité des Ministres du Conseil de l'Europe [Council of Europe Strategy for Gender Equality 2018-2023. Adopted by the Committee of Ministers of the Council of Europe]. https://www.coe.int/fr/web/genderequality/genderequality-strategy

Equality and Human Rights Commission. (n.d.). Article 1 of the First Protocol: Protection of property. https://www.equalityhumanrights.com/en/human-rights-act/article-1first-protocol-protection-property

European Convention on Human Rights. S.A.S. v. France. Application no. 43835/11. https://www.justiceinitiative.org/litigation/sas-v-france

European Court of Human Rights. (1950). European Convention on Human Rights. https://www.echr.coe.int/documents/convention_eng.pdf

European Court of Human Rights. (1993). Case of Schuler-Zgraggen v. Switzerland. Application no. 14518/89. https://hudoc.echr.coe.int/eng\#\{\%22itemid $\% 22:[\% 22001$ $\underline{57840 \% 22]\}}$

European Court of Human Rights. (1997). Case of $V$ an Raalte v. The Netherlands. Application no. 20060/92. http://hudoc.echr.coe.int/webservices/content/pdf/001$\underline{58031}$ ? TID $=$ qunacxamrv

European Court of Human Rights. (2002). Case of Willis v. the United Kingdom. Application no. 36042/97. https://www.womenslinkworldwide.org/files/2991/gjo-echr-willis-enpdf.pdf

European Court of Human Rights. (2006). Case of Zarb Adami v. Malta. https://rm.coe.int/6120252-v1-legal-summaries-gender-equality-helpeng/1680907208

European Court of Human Rights. (2009). Case of Opuzv. Turkey. Application no. 33401/02. Judgment. https://hudoc.echr.coe.int/sites/fra/pages/search.aspx?i=003-2759276$\underline{3020932}$ 
European Court of Human Rights. (2012). Konstantin Markin v. Russia. Application no. 30078/06. https://hudoc.echr.coe.int/ukr\#\{\%22itemid\%22:[\%22001$109868 \% 22]\}$

European Court of Human Rights. (2016). Case of Irina Smirnova v. Ukraine. Application no.1870/ 05.

https://hudoc.echr.coe.int/app/conversion/pdf?library $=$ ECHR\&id=00355171956939512\&filename $=J u d g m e n t s ~ \% 20$ and $\% 20$ decisions $\% 20$ of $\% 2013.10 .16$.pdf

European Court of Human Rights. (2017). Case of Khamtokhu and Aksenchik v. Russia. Applications nos. 60367/08 and 961/11. https://www.conjur.com.br/dl/russiaprisao-perpetua-homens.pdf

European Court of Human Rights. (2020). Carvalho Pinto de Sousa Morais v. Opuz l. Application no. 17484/15. https://rm.coe.int/case-of-levchuk-v-ukraineeng/16809fd60a

European Court of Human Rights. (2020). Case of Levchuk v. Ukraine. Application no. 17496/19. https://rm.coe.int/case-of-levchuk-v-ukraine-eng/16809fd60a

European Court of Human Rights. Case of Belyayev and others v. Ukraine. Application no. 34345/10. http://hudoc.echr.coe.int/app/conversion/docx/?lib

European Court of Human Rights.(2005). Case of Leyla Şahin v. Turkey. Application no. 44774/98. https://hudoc.echr.coe.int/tur\#\{\%22itemid\%22:[\%22001-70956\%22]\}

European Court of Human Rights.(2009). Case of_V.C. v. Slovakia. Application no. 18968/07. https://www.refworld.org/pdfid/4a648cb42.pdf

European Court of Human Rights.(2011). R.R. v. Poland. http://hudoc.echr.coe.int/fre?i=001-104911

European Court of Human Rights.(2014). Case of Konovalova v. Russia. Application no. 37873/04 https://hudoc.echr.coe.int/fre\# \{\%22itemid $\% 22:[\% 22002-10150 \% 22]\}$

European Disability Forum.(n.d.). Instanbul Convention https://www.edffeph.org/content/uploads/2020/12/istanbul convention easy-toread english.pdf

Karvatska, S., \& Toronchuk, I. (2020). The Right to Non-Discrimination: Interpretive Practice of the Ecthr. European Journal of Law and Public Administration. 7(2), 24-38. https://doi.org/10.18662/elipa/7.2/124

Law of Ukraine "On Ensuring Equal Rights and Opportunities for Women and Men" of September 8, 2005 № 2866-IV. https://zakon.rada.gov.ua/laws/show/2866-15\#Text [In Ukrainian]

The Penal Code of Ukraine. https://www.legislationline.org/documents/section/criminalcodes/country/52/Ukraine/show 